\title{
Alerters, Critics, and Objectivists: Researchers in Austrian Newspaper Coverage of Climate Change
}

\author{
Andrea Tony Hermann ${ }^{1,2^{*}}$, Markus Pikl ${ }^{1}$, Anja Bauer ${ }^{3}$ \\ 1 Institute of Forest, Environmental, and Natural Resource Policy, University of Natural Resources and Life Sciences, Vienna, Austria \\ 2 Doctoral School Sustainable Development of the University of Natural Resources and Life Sciences, Vienna, Austria \\ 3 Institute of Technology Assessment, Austrian Academy of Sciences Vienna, Austria \\ * andreatony.hermann@gmail.com
}

\begin{abstract}
Newspapers are important fora for communicating scientific expertise to the public. Our article asks how researchers convey their expertise and link it to political actions in Austrian newspaper coverage of climate change. Based on researchers' understanding of climate change and the degree of prescriptiveness of their policy recommendations, we identify three positions: alerters, critics, and objectivists. We illustrate how these three types advance different framings of the climate change debate and generate contradictory representations of climate science. Finally, we discuss our findings against the background of scholarly works on the nationally specific media representation of climate research.
\end{abstract}

\section{Keywords}

researchers, climate change, climate policy, media analysis, newspapers, Austria

\section{AlarmistInnen, KritikerInnen und ObjektivistInnen: ForscherInnen in der österreichischen Zeitungsberichterstattung über den Klimawandel}

\section{Zusammenfassung}

Zeitungen sind wichtige Foren für die Kommunikation wissenschaftlicher Expertise an die Öffentlichkeit. Unser Beitrag fragt, wie WissenschafterInnen in der österreichischen Zeitungsberichterstattung zum Klimawandel ihre Expertise vermitteln und mit politischen Handlungen verknüpfen. Auf Basis ihres Klimawandelverständnisses und des Umfangs präskriptiver Politikempfehlungen identifizieren wir drei Positionen: WarnerInnen, KritikerInnen und ObjektivistInnen. Wir zeigen, wie diese drei Typen verschiedene Rahmungen der Klimawandeldebatte fördern und gegensätzliche Bilder von Klimawissenschaft zeichnen. Abschließend diskutieren wir unsere Ergebnisse vor dem Hintergrund wissenschaftlicher Arbeiten zur länderspezifischen Mediendarstellung von Klimaforschung.

\section{Schlüsselwörter}

WissenschafterInnen, Klimawandel, Klimapolitik, Medienanalyse, Tageszeitungen, Österreich

The authors have declared that no competing interests exist. 


\section{Introduction}

Scientific expertise plays an important role in defining complex policy issues as well as identifying and legitimizing corresponding options for political and societal action. Climate change is a prime example of such a complex and contested issue. Scientists' knowledge has been central to the emergence and development of climate policy and is particularly represented in advisory bodies, such as the Intergovernmental Panel on Climate Change (IPCC) (Hustedt 20I3). However, the communication of climate issues to broader audiences entails severe pitfalls: climate change lacks visibility and immediacy, especially with regard to its causes. Many recipients of this information perceive climate change impacts as temporally and geographically distant, and they have difficulty understanding the link between current actions and long-term climate change. Narrow interest-driven debates and conflicting values further inhibit lay audiences from fully grasping the consequences of climate change and prompt people to consider other topics more relevant (Moser 20I0; Neverla/Schäfer 20I2). Conveying scientific knowledge on climate change compounds these communication challenges. Because scientific findings are multilayered and highly complex, it is difficult for non-scientific audiences to entirely understand the issue at hand. The preliminarity of research findings and the high degree of uncertainty in some research areas hamper immediate measures because most lay audiences do not perceive the evidence as clear and compelling (Moser 20IO). These difficulties require the simplification and translation of research findings to improve their comprehensibility and approachability.

The large presence of researchers in political debates on climate change has intensified scholarly interest in the complex relationship among media, research, politics/ policy, and the public. Studies, inter alia, address the functions of mass-mediated scientific knowledge. In particular, newspapers provide important fora for the multiplication, amplification, and translation of research findings on climate change to policy-makers and broader audiences (Peters 20I3). Therefore, the media contribute considerably to the public understanding of complex policy problems, the formation of public opinions on policy issues, and political agenda-setting (Carvalho 2007; Rhomberg 2012). Drawing on these insights, another scholarly strand of literature stresses the strategic use and transformation of researchers' expertise in mass media contexts (Anderson 2009; Boykoff 2007). It demonstrates that newspapers provide arenas for multifaceted climate debates in which not only journalists and policy-makers but also researchers strategically articulate their know- ledge claims on climate change (Carvalho 2007; Rhomberg 2012).

Although climate change is characterized as a global challenge, scholars emphasize that nationally specific factors are highly important for the way information and opinions are presented. The representation of climate change and scientific climate expertise is embedded in distinct national media systems, journalistic cultures, knowledge cultures, and political cultures (Neverl/Trümper 20I2; Olausson 2009; Schäfer et al. 20I2; Kleinschmidt/Sjösted 2OI4). For instance, the US media tend to equally represent scientists who argue in favor of and against anthropogenic climate change (Boykoff/Boykoff 2007). By comparison, in the German media, researchers substantiating the anthropogenic component of climate change clearly prevail. So far, studies on the media representation of science have primarily focused on a few paradigmatic countries, particularly the US, the UK, and Germany, whereas smaller countries, including Austria, have rarely been considered. The few media analyses that exist for Austria have primarily addressed the general relation among media, politics, and the public. Scholars have studied Austrian media data, the media's agenda-setting functions, and political communication by the mass media (e.g., Filzmaier et al. 2007; Plasser 2010). Only scattered works address issue-specific media coverage, such as right-wing populism (Plasser/Ulram 2003) or economic policy (Beyrl/Perlot 2006). With the exception of one study on the communication of climate adaptation measures in Austria and nine additional OECD countries (Wirth et al. 20I4), scholars have never placed a dedicated emphasis on climate change.

Against this background, our article addresses the newspaper coverage of climate change in Austria. Specifically, we ask how researchers position themselves in print media. To reconstruct different positions, we draw on analytical dimensions derived from scholarly findings on types of researchers in policy debates (section 2) and a qualitative content analysis of interviews with and guest commentaries of researchers in four Austrian newspapers (section 3). In section 4 , we present three distinct types of researchers - alerters, critics, and objectivists - and illustrate their positions on climate change, climate science, and political and societal actions. Finally, we conclude by discussing our findings in light of the literature on the nationally specific media representation of climate research (section 5).

I In accordance with the relevant scholarly literature, we use the terms 'scientists', 'researchers' and 'scientific' to refer to both natural and social science. 


\section{Heterogeneous Expertise: Researchers in Public Policy Debates}

Scholarly works have emphasized the role of scientific consensus in policy advice on environmental and technical issues (Oreskes 2004), such as in the context of epistemic communities (Haas I992). Epistemic communities are groups of experts that produce policy-relevant knowledge about complex issues (Haas I992). Their authoritative claim to define policy problems and solutions is based on shared normative and causal beliefs, shared notions of validity and a shared policy enterprise (Haas 1992). Epistemic communities' exclusive control over knowledge production is challenged when multiple epistemic communities exist that contest the epistemic and value consensus (Dunlop 2013).

Scholars increasingly observe this plurality and heterogeneity of scientific expertise due to diverging political, cultural, and institutional contexts and due to the diversity of scientific disciplines and epistemic cultures (Jasanoff I990; Knorr Cetina I99I; Sarewitz 2004). This heterogeneity manifests in the different roles that researchers adopt in policy debates. Scholars demonstrate that researchers strategically draw on academic knowledge to position themselves in public debates. In varying contexts, researchers present distinct bodies of academic knowledge, interpret academic findings differently, and play a political role by providing informed opinions on policy-making (Oreskes 2004; Pielke 2007; Spruijt et al. 20I4). As one of the most prominent exponents of this strand of literature, Pielke (2007) primarily draws on the degree to which researchers interact with and provide policy alternatives for decision-makers to identify four ideal types of researchers in policy debates: the Pure Scientist, who is driven by scientific curiosity only without considering the utility of advice for decision-makers; the Science Arbiter, who directly interacts with decision-makers but stresses the technicalscientific core of policy-relevant issues; the Issue Advocate, who politicizes debates, advocates particular policy options and is frequently allied with particular interest groups; and the Honest Broker of Policy Alternatives, who aims to connect and mediate science and politics by providing a range of policy options.

Regarding media reporting on climate change, scholars primarily distinguish between alarmists and skeptics as two ends of a continuum on which researchers locate themselves or are positioned by other actors. Alarmists are convinced that anthropogenic climate change is scientifically proven and that the theoretical assumptions and methodological approaches of mainstream science are sound. They use their knowledge to advance ambitious climate targets and comprehensive measures, such as $\mathrm{CO}_{2}$ reduction goals or the use of renewable energies. In contrast, skeptics reject the scientific foundations of anthropogenic climate change and the political and societal measures derived from this basis (Boykoff/Boykoff 2007). Some scholarly works analyze skeptics in detail (Antilla 2005; Boykoff 2013; Whitmarsh 20II) and distinguish between different types of skepticism. Doubts about the existence and causes of climate change find their expression in either trend skepticism, which basically denies climate change, or attribution skepticism, which sees only natural causes for the phenomenon. Impact skeptics perceive the effects of climate change as harmless or even beneficial, whereas action skeptics criticize the costs and utility of measures to combat climate change.

Against the background of these studies, we expect that researchers differ in their positions in Austrian newspapers. We deduce two analytical dimensions from the literature outlined above that serve to identify specific types of researchers in Austrian newspapers. First, the researchers' understanding of climate change is expected to vary with regard to (a) the existence and causes and (b) the impacts of climate change. Second, the degree of prescriptiveness of policy recommendations inherent in researchers' statements might range from (a) no conclusions to (b) the provision of different options to (c) the recommendation of specific measures.

Previous studies on types of climate researchers have focused on in-depth analyses of a specific, primarily extreme, type (e.g., Boykoff 20I3; Oreskes/Conway 20I0; Risbey 2008) or have provided overviews of different types that are embedded in more comprehensive works on the representation of research in mass media. Our article aims to provide a systematic, illustrative, indepth analysis that reveals researchers' strategies and lines of argumentation to convey their positions. Therefore, we have refined and complemented the analytical dimensions from the scholarly literature with dimensions and categories derived from the empirical material (see 4).

\section{Research Framework}

\subsection{Austrian Newspaper Landscape and Case Selection}

Hallin and Mancini (2004) consider the Austrian media system a typical democratic-corporatist one. This type of national system is characterized by a highly developed newspaper industry, political parallelism that is currently replaced by a commercial press, a high degree of professionalization, and a strong role of the state. Democratic-corporatist media systems feature a specifically important role of newspapers for public discourse compared to other media. Even in times of growing relevance of the Internet and social media in Austria (Digital Affairs 2016), newspapers remain a defining medi- 
um and showed a broad distribution of $72.5 \%$ among the population in 2012 (Bundeskanzleramt 2014). They still rank as the second most important source of information for the Austrian electorate after television, considerably ahead of the Internet (Lengauer et al. 2012). Austrian newspapers broaden their audiences through their online news platforms. Beyond its importance for Austrian societal discourse, a newspaper analysis is particularly fruitful because of the relative ease of access (Filzmaier et al. 2007; Hallin/Mancini 2004).

The Austrian newspaper landscape exhibits relative media poverty compared to other European countries. Three newsstand newspapers and two free daily newspapers dominate the market (Kaltenbrunner et al. 2007; Seethaler/Melischek 2006). Austrian newspapers exhibit a high degree of organization, professionalization, and institutionalization (Pelinka 2003). The Austrian press is politically independent, opinion journalism is decoupled from party lines, and newspapers position themselves as societal advocates. Nevertheless, newspapers can be clearly attributed to a specific ideological orientation, ranging from conservative to liberal (Filzmaier et al. 2007; Seethaler/Melischek 2006).

Our analysis focuses on four Austrian newspapers: Kronen Zeitung, Kleine Zeitung, Die Presse, and Der Standard. This selection was based on the aim of achieving an illustrative picture of the different positions of researchers across the Austrian newspaper landscape. The titles cover different newspaper types, span the ideological spectrum, and exhibit wide coverage. Whereas Kronen Zeitung and Kleine Zeitung are mass newspapers, Die Presse and Der Standard are categorized as premium press. Kleine Zeitung can be attributed to the mid-market segment, located between boulevard and quality press, and Kronen Zeitung represents the boulevard media. Die Pres$s e$ is ascribed a bourgeois-conservative orientation, and Der Standard leans toward the leftist-liberal spectrum (Magin/Stark 20II). The four newspapers exhibit the highest degrees of coverage in their segment. Together, these four newspapers reach approximately $60 \%$ of the Austrian newspaper audience (Statistik Austria 2OI3).

\subsection{Period of Analysis and Methods}

We chose the year 2009 as the period of analysis to explore and illustratively reconstruct the positioning of researchers in Austrian newspapers because this was a key period for the discursive attribution of meaning to climate change. A keyword search for "climate change" ("Klimawandel") in the selected newspapers in the Austrian National Library (ÖNB) newspaper database revealed the years with the highest intensity in newspaper coverage of climate change between 2002 and 2012. "Climate change" received the broadest cov- erage in all four newspapers in 2007, 2008, and 2009. The increased media reporting on the upcoming $15^{\text {th }}$ Conference of Parties to the United Nations Framework Convention on Climate Change (COP I5) in Copenhagen (Denmark), as a focal event for future international climate policy, as well as the so-called 'Climategate' (i.e., the hacked emails of IPCC researchers) triggered particularly broad newspaper coverage in 2009 of climate policy and scientific climate expertise in many countries (Neverla/Schäfer 20I2).

The keyword search provided a corpus of I.2IO articles on "climate change" from OI.OI.2009 to 31.12.2009 considering all journalistic genres, from features to editorials. Because we were interested in researchers' positioning, we selected only interviews and guest commentaries as narrative, opinion-oriented formats of journalistic presentation (Neverla/Trümper 2012). These formats enable researchers to articulate their own perspectives more comprehensively, whereas journalists select, edit, and transform researchers' expertise more strongly in other formats. Overall, 39 contributions, 24 interviews and 15 guest commentaries, were published in the four selected newspapers in 2009 (in the following sections, coded as Ci to C39). The pieces were mainly found in the premium press: 25 contributions in Der Standard, followed by Die Presse with 8, the Kronen Zeitung with 4, and the Kleine Zeitung with 2 contributions.

To reconstruct different types of scientists in the selected articles, we applied qualitative content analysis (Gläser/Laudel 20IO), facilitated by MAX QDA ${ }^{\circledR}$. The coding and interpretation of the newspaper articles followed deductively and inductively developed dimensions and categories. First, the analytical dimensions and their manifestations found in the literature (chapter 2) served as the main categories and corresponding sub-categories for the initial deductive coding of the interviews and guest commentaries. As expected, we found variances in the first dimension, the researchers' understanding of climate change, with regard to (a) the existence and causes of climate change and (b) the impacts of the phenomenon, inter alia, the causal linkages between climate change and extreme weather events. These understandings range from consensus on anthropogenic climate change to perspectives that question anthropogenic contributions. Regarding the second analytical dimension, the degree of prescriptiveness, we found no differences because all researchers provide specific recommendations for political and societal actions. This deductive analysis led to a preliminary typology of three positions, alerters, critics, and objectivists, primarily based on the differences in the researchers' understanding of climate change.

We inductively identified additional dimensions and categories to distinguish scientists' positions, strategies, 
and lines of argumentation to test, stabilize, and enrich these types. First, we found that researchers advance different framings of the climate change debate by drawing on varying thematic foci in their statements. Researchers either directly position themselves toward climate policy or convey their arguments indirectly by addressing the role of science in decision-making. Second, our analysis revealed that the divergent understandings of climate change (see above) and the different thematic foci generate different representations of climate science. Researchers portray climate science as either homogenous and consensual or heterogeneous and diverging. Accordingly, scientific knowledge on climate change is presented as either clear and compelling or ambiguous and not compelling. Third, although we found strong political advocacy in all types (see above), the direction and content of specific policy recommendations varied considerably. Perspectives on climate policy range from the endorsement of strong political, societal, and economic actions and transformations to the rejection of climate policy and its principles. Finally, we found that scientists employ several rhetorical devices, such as metaphors or specific wording, to enhance the comprehensibility of their arguments. The coding and interpretation of the articles were iteratively adapted along these newly identified dimensions and categories until saturation was reached and the typology proved to be robust.

\section{Three Types of Researchers in Austrian Newspapers}

Overall, 34 different researchers presented their perspectives on climate change issues in the analyzed interviews and guest commentaries. Seven researchers appeared twice as an interviewee and/or author of a guest commentary, and one guest commentary was jointly written by three researchers. Seventeen pieces were authored by Austrian researchers, including eleven natural scientists and six social scientists. Twentytwo articles featured international researchers, particularly from the US, including five natural scientists and I7 social scientists. Among national and international social scientists, economists dominated with 13 contributions versus ten contributions from other social science disciplines.

As outlined above, we identified three distinct types of scientists discussing climate change in Austrian newspapers: alerters, critics, and objectivists. In the following, we present these three types with regard to the introduced analytical dimensions: the thematic focus, the understanding of climate change, the representation of climate research, the direction and content of policy recommendations, and the rhetorical devices (see also Table I).

\section{Alerters}

The alerter is by far the most dominant type in Austrian newspaper coverage of climate change, with 23 contributions. This type is almost equally composed of natural and social scientists with both national and international backgrounds. Alerters represent the IPCC consensus on anthropogenic climate change and strongly warn about its consequences. Accordingly, they demand comprehensive political and societal actions. Alerters primarily frame climate change as a natural and societal problem that requires far-reaching efforts in national and international climate policy.

In their statements on the main causes of climate change, alerters exclusively address anthropogenic contributions. They describe the nexus between the growth of human activities, $\mathrm{CO}_{2}$ emissions, and climate change over the last decades as a causal, scientifically proven relationship:

"Humans are responsible [for climate change, ATH] because they release 32 billion tons of $\mathrm{CO}_{2}$ per year to the protective atmosphere by burning fossil fuels" (C39).

Alerters stress the economic, political, and social causes of anthropogenic climate change. They particularly identify societies' paradigmatic orientation toward economic growth as a central reason for anthropogenic climate change. This orientation leads to a prioritization of political and economic interests and $\mathrm{CO}_{2}$-intense lifestyle over climate-friendly considerations.

Alerters warn of the negative effects of climate change by illustrating its impacts. They strongly emphasize the ecological effects. Some of them even note that anthropogenic climate change accompanies a "tendency toward extreme weather events" $\left(C_{3}\right)$. They define climate change not only as an ecological problem but also as a political, social, and economic issue. For instance, an Austrian researcher demonstrates the interconnectedness of the economic and social effects of climate change:

"Many densely populated coastal areas will no longer exist in a few decades; compared to future migration movements, the current migratory pressure is low; desertification, sales, and alienation of producing areas will raise food prices, and the pressure of riots caused by hunger and political-religious radicalization in the South will transform the rich countries of the North-West into paranoid police states. The polarization of humanity into few prosperous ones and many death-consecrated ones will make the craziest post-nuclear war scenarios look completely ridiculous" (C28). 
The researchers' statements reflect the scientific consensus on anthropogenic climate change as advanced by the IPCC. They illustrate the group of climate researchers as relatively homogenous. Researchers' knowledge of the phenomenon is clear and compelling. To substantiate their position, alerters frequently draw on scientific expertise that is in line with their arguments. Scientific uncertainties are frequently introduced to stress the urgency of the problem:

"Earlier model simulations were rather conservative, modest. Wherever we conducted simulations in the I990s for the year 20I0, reality exceeded them. Reality has shown that climate trends are much more dynamic and rapid than expected" (CI).

Against the background of severe climate change impacts, alerters directly address climate policy and portray national and international measures as inadequate and ineffective. They criticize economic, political, and societal solutions as not sufficiently comprehensive:

“These [recently applied, ATH] concepts' [i.e., political approaches, ATH] range is strongly confined, and they do not achieve what would be necessary: a farreaching modification of the capitalist-fossil mode of production and lifestyle" ( $\left.\mathrm{C}_{17}\right)$.

Alerters call for immediate political and societal actions to tackle climate change. Generally, they favor a holistic and coherent long-term approach and warn of inaction. More concretely, alerters express clear preferences for specific climate mitigation measures, such as a shift from individual to public transportation (CIO, I5, I6). These researchers call for comprehensive technical, economic, political, and societal transformations at different political levels for this purpose. Some researchers address only one policy domain, whereas others complementarily suggest cross-cutting approaches that encompass different policy areas. In particular, the balance of economic and climate policy is frequently demanded. Although they criticize neo-liberal economic behavior, these researchers attempt to adopt neo-liberal lines of argumentation. For instance, alerters advocate the necessity of environmentally friendly, low carbon energy technologies by drawing on a costbased argumentation $(\mathrm{C} 6,36)$. In addition to concrete suggestions, alerters clearly exclude specific approaches. For instance, one researcher emphasizes that the EU cannot be the only contributor to emission reduction worldwide. Instead, he proposes burden sharing with the US and China (C28). Overall, researchers support the guiding principles of international and intergenerational justice in climate policy. On a global level, alerters advocate the polluter principle and burden sharing, particularly with regard to industrialized and emerging countries' responsibility toward developing countries.

Alerters frequently use dramatizing metaphors and wording to express their concern. For instance, an African researcher and activist accused Connie Hedegaard, the host of the COPI5 on behalf of the Danish government, of aiming to "kill Kyoto" (C8). Demands are frequently accompanied by strong wording, such as "must" or "necessary", to stress the necessity and urgency of their claims.

\section{Critics}

Critics are a small group of researchers in Austrian newspapers, with six contributions, mainly guest commentaries. This group is primarily composed of international natural and social scientists. These researchers adopt a position that opposes alerters by challenging the IPCC consensus on the existence, causes, and impacts of anthropogenic climate change. Accordingly, critics advocate the cessation of ambitious climate policy and its guiding principles. However, they rarely convey their position directly. Instead, critics use the role of research in political and public debates as an entry point to undermine the scientific consensus on climate change and the corresponding political and societal actions.

In their statements, critics challenge the dominant understanding of anthropogenic climate change by arguing that it is not caused by humans but is a general, natural trend. Another strand of argumentation questions the extent of anthropogenic contributions to the phenomenon. These researchers also reject the notion of causal linkages between the phenomenon and extreme weather events.

Critics present climate researchers as a heterogeneous group and portray scientific knowledge as ambiguous and not compelling. They distinguish themselves from the scientific consensus on anthropogenic climate change and conceive of themselves as the "real" representation of science. Their statements particularly aim to challenge the credibility of the "scientific mainstream" (C9, 26, 3I). Mainstream scientists are frequently deemed "alarmists" or "alarming" $\left(C_{9}, 26\right)$ and are blamed for imagining "doomsday scenarios" ( $\mathrm{C}_{3} \mathrm{I}$ ) that are not scientifically sound. These researchers accuse proponents of consensus of not adequately reflecting on scientific uncertainties. They introduce counterexpertise and emphasize uncertainties to deconstruct the powerful position of the scientific consensus. One researcher, for instance, substantiates his doubts about the extent of anthropogenic contributions to climate change by stressing scientific uncertainties: 
"We know that the sea level has risen approximately Ioo meters over the last 12.000 years. This rise is clearly linked to glacier meltdown of continental ice sheets at the end of the last ice age - it was not connected to human activities in any way. Over the course of the last 200 years [...], sea level has slowly risen. We do not know the extent to which the latest rise has been caused by human activities. Glaciers melt for hundreds of years, while human activities have gained in importance only over the last century" (C3I).

These researchers adopt a particularly critical stance toward the representation of research in decision-making to delegitimize the scientific consensus and approaches to combat climate change. They invoke democratic principles, such as representativeness and inclusiveness, to question the legitimacy of international scientific advisory bodies. Mechanisms of exclusion are found in the sole integration of mainstream scientists and the disregard of outlier views in international decision-making processes. One researcher emphasizes that advisory bodies do not represent the entire spectrum of existing scientific perspectives and notes how this imbalance is constantly reproduced:

"What I criticize is the practice of choosing the socalled lead authors from the group of the particularly visible [scientific, $\mathrm{AH}$ ] experts from the respective realm. Those who have published most on an issue and who, then, as lead authors of the IPCC report, let their own works and the works of their immediate peer group dominate. This does not result in a very broad range of views being represented there" (C9).

Drawing on these insights, critics demand changes in the structure of international advisory bodes and thereby question the credibility and legitimacy of scientific expertise in decision-making. Consensus orientation is mostly rejected in this regard. First, critics make suggestions for the future behavior of scientists. Researchers who represent the scientific consensus should properly and openly reflect on the scientific uncertainties of the findings to which they refer. Second, they indicate that the organizational integration of researchers into policy-making should be revised. For instance, critics advocate more adversarial ways of fact-finding and debate through the integration of outlier views into advisory bodies. A third strand of suggestions refers to the interaction between researchers and policy-makers. Critics frequently demand more controversial debates between researchers and policy-makers. More diverse scientific perspectives should be articulated and made accessible to policy-makers before decision-making. Moreover, the international community should revisit its structures to allow for a broader public understanding of science.

Ultimately, the critique of mainstream science's role in international climate policy provides a means to scrutinize the aptness and necessity of climate mitigation policy and to substantiate the claim for its termination. Researchers argue that due to the scientific mainstream in climate policy debates, an incorrect understanding of climate change prevails. Critics aim to demonstrate that the presentation of scientific findings in this incorrect, alarming way results in the prioritization of political values over scientific evidence:

"The two-degree target is a political figure, not a scientific one, even if it was declared to be a guiding principle" (C35).

Because solutions draw on the expertise of mainstream scientists who do not properly represent the scientific state of the art, critics demand the cessation of the guiding principles of international climate policy. Current measures are based on an ill-defined perception of the problem. Therefore, nothing hinders a growthoriented, fossil-fuel-based economy. For instance, one researcher challenges widely accepted principles and targets, such as $\mathrm{CO}_{2}$ reduction goals for emerging economies $\left(\mathrm{C}_{3} \mathrm{I}\right)$. The researchers stress the importance of economic development as a guiding notion instead of adhering to the precautionary principle. Simultaneously, these researchers exclude specific pathways by rejecting the substitution of fossil energy sources with renewable energies.

The adversarial positioning of critics toward the consensus of most researchers and policy-makers is substantiated by their wording and metaphors. For instance, one researcher compares the COPI5 to biblical events to evoke an apocalyptic mood:

"The Copenhagen Conference, which aimed to decide crucial measures to combat potential atmospheric warming, ends in these days of bone-chilling cold. It is a gigantic media event, only comparable to the first big councils of Nicea, Constantinople, Ephesus, Chalzedon, when a triumphant Church conceived of itself as the keeper of the message that was supposed to set the pagan world on fire" (C25).

\section{Objectivists}

Objectivists position themselves between alerters and critics and thus aim to convey an aura of neutrality and objectivity. They were found in nine contributions that almost equally encompassed national natural scientists and international social scientists. By addressing cli- 
mate policy and the role of science in decision-making, their thematic foci reflect the main concerns of the previous types.

Generally, objectivists draw on the notion of anthropogenic climate change. However, they aim to convey their neutral position by presenting both anthropogenic and natural causes of climate change:

"[W]e recognize natural climate drivers that have been and will be operative over the past and future decades and centuries and those drivers to which we [as human beings, ATH] contribute" $\left(\mathrm{C}_{27}\right)$.

Objectivists additionally stress that there is no scientific proof for a causal link between climate change and extreme weather events:

"It is acknowledged that human beings, among additional factors, contribute to global warming and that glacial melting and sea-level rise exist. However, there are no substantiated [scientific, ATH] statements on hurricanes - and there is no evidence for a future increase in storms in the mid-latitudes or for an increase over the last I50 years" ( $\mathrm{C}_{22}$ ).

Objectivists present climate researchers as a heterogeneous group with different perspectives on climate change. However, objectivists consider the scientific knowledge on anthropogenic and natural causes of climate change basically clear and sufficiently compelling. Like critics, objectivists challenge the role of science in climate policy debates but question both "alarmist" and "critical" voices (CII, 27) in political and public debates. Objectivists distinguish themselves from alarmists and critics to present themselves as neutral advisors. Both types are accused of exaggerating scientific facts and, therefore, distorting the image of climate science. Objectivists believe that these inappropriate representations of science not only jeopardize the credibility of scientific expertise but eventually also present a central problem for effective climate policy. The debates surrounding alarmist and critical voices and the fact that they result in the public challenging of the credibility of science overlap the actual problem of climate change and inhibit its solution.

These researchers also perceive current political approaches to address climate change as core problems of climate policy and claim to re-focus the debate on neutral assessments. Objectivists aim to demonstrate balanced assessments by simultaneously addressing the weaknesses and potentials of political, economic, and social measures. Although objectivists discuss different courses of action to resolve the climate change issue, ultimately, they explicitly favor one specific option. For instance, an Austrian researcher outlines different sce- narios for future international climate policy but concludes his statement with a clear positioning:

"In my opinion, there exist three pathways to the future, and Copenhagen represents one of them - the one that saves as many greenhouse emissions as possible through international agreements. [...] It is possible that we drift into a climate dictatorship this way. $[\ldots]$ The second pathway is the 'ugly globalization'. It comes along with wars and further increasing differences in prosperity worldwide. [...] With and without Copenhagen, I hope for a third way: that a broad globalization starts in which the economy realizes that it needs customers for its business. With this third way, the economy hits the road by itself to offer its customers resource-efficient and low-energy products. This would lead to lower differences in prosperity worldwide [...]" (C22).

In contrast to alerters, objectivists advocate comprehensive approaches that encompass not only mitigation but also adaptation measures. For instance, they demand a lifestyle based on renewable energy and propose the energy efficient redevelopment of buildings $(\mathrm{C} 22,33)$ as mitigation measures. Regarding adaptation, they suggest, for example, extended dyke construction and the breeding of more drought- and temperature-resistant plants (Ci2, 23). The presented technological, economic, political, and societal options encompass regional, national, and international actions. The recommendations either cross the boundaries of policy domains or cover different measures within one policy domain. For instance, one researcher suggests a complementary approach of national and international regulations, awareness-raising among societal actors, and the development and use of new technologies $\left(\mathrm{C}_{23}\right)$. The clear political positioning of objectivists is also reflected in their explicit exclusion of specific solutions. They particularly reject nuclear energy as an alternative energy source for replacing fossil fuels (CII, I2, 34).

The objectivists' positioning as objective commentators is reinforced by their rhetorical strategies. Contradictory wording substantiates their apparent neutrality: when they talk about other researchers, they tend to use pejorative wording, such as "extreme" or "exaggerated" $(\mathrm{C} 22,27)$. Their own arguments are frequently advanced by neutral and impersonal wording, such as "no substantiated statements on" $\left(\mathrm{C}_{22}, 23\right)$. Moreover, objectivists use metaphors that illustrate challenging, long-term processes. For instance, the statement of an Austrian researcher compares the way ahead in climate policy with a difficult ski slope:

"There are a range of further gates to pass in our climate change slalom that consist of contradictions, 
Table 1: Types of Researchers in Austrian Newspaper Coverage of Climate Change

\begin{tabular}{|c|c|c|c|}
\hline $\begin{array}{l}\text { Analytical } \\
\text { dimension }\end{array}$ & Alerters & Critics & Objectivists \\
\hline Thematic focus & $\begin{array}{l}\text { - Natural and social impacts of } \\
\text { anthropogenic climate change } \\
\text { - Problems of national and } \\
\text { international climate policy and } \\
\text { their solution }\end{array}$ & $\begin{array}{l}\text { - Role of mainstream scientists in } \\
\text { climate policy } \\
\text { - Revision of international } \\
\text { advisory structures }\end{array}$ & $\begin{array}{l}\text { - Role of alarmist and skeptical } \\
\text { voices in climate policy debates } \\
\text { - Assessment of and solution } \\
\text { approaches for national and } \\
\text { international climate policy }\end{array}$ \\
\hline $\begin{array}{l}\text { Understanding } \\
\text { of climate } \\
\text { change }\end{array}$ & $\begin{array}{l}\text { - IPCC consensus on climate } \\
\text { change } \\
\text { - Anthropogenic climate change } \\
\text { - Some see a causal link to } \\
\text { extreme weather events } \\
\text { - Severe ecological, economic, and } \\
\text { societal impacts }\end{array}$ & $\begin{array}{l}\text { - Rejection of IPCC consensus } \\
\text { - Climate change as a general } \\
\text { trend/extent of anthropogenic } \\
\text { contributions not clear } \\
\text { - No causal relation to extreme } \\
\text { weather events }\end{array}$ & $\begin{array}{l}\text { - IPCC consensus on climate } \\
\text { change } \\
\text { - Anthropogenic contributions and } \\
\text { additional triggering factors } \\
\text { - No scientifically proven causal } \\
\text { link to extreme weather events }\end{array}$ \\
\hline $\begin{array}{l}\text { Representation } \\
\text { of climate } \\
\text { research }\end{array}$ & $\begin{array}{l}\text { - Researchers presented as } \\
\text { relatively homogeneous group } \\
\text { - Researchers' knowledge } \\
\text { presented as clear and } \\
\text { compelling } \\
\text { - Researchers' expertise to } \\
\text { substantiate own arguments } \\
\text { - Uncertainties stress the urgency } \\
\text { of actions }\end{array}$ & $\begin{array}{l}\text { - Researchers presented as } \\
\text { relatively heterogeneous group } \\
\text { - Researchers' knowledge } \\
\text { presented as ambiguous and not } \\
\text { compelling } \\
\text { - Demarcation from alarmist } \\
\text { mainstream science, } \\
\text { own position as the 'real' } \\
\text { representation of research } \\
\text { - Critique of outlier views' } \\
\text { exclusion in advice-giving } \\
\text { - Scientific evidence as counter- } \\
\text { expertise } \\
\text { - Uncertainties indicate the lack of } \\
\text { substantial knowledge }\end{array}$ & $\begin{array}{l}\text { - Researchers presented as more } \\
\text { heterogeneous group } \\
\text { - Scientific knowledge as clear and } \\
\text { compelling enough } \\
\text { - Demarcation from both alarmist } \\
\text { and skeptical researchers, } \\
\text { present themselves as neutral } \\
\text { advisors } \\
\text { - Exaggerated scientific debates } \\
\text { overlap the actual problem of } \\
\text { climate change and inhibit its } \\
\text { solution }\end{array}$ \\
\hline $\begin{array}{l}\text { Direction and } \\
\text { content of } \\
\text { policy recom- } \\
\text { mendations }\end{array}$ & $\begin{array}{l}\text { - Current approaches are } \\
\text { inadequate and ineffective, } \\
\text { necessary measures not } \\
\text { implemented yet } \\
\text { - Immediate, comprehensive } \\
\text { political actions and societal } \\
\text { transformations for successful } \\
\text { climate mitigation } \\
\text { - Exclusion of specific solution } \\
\text { approaches }\end{array}$ & $\begin{array}{l}\text { - Critique of mainstream science's } \\
\text { role as means to question the } \\
\text { accuracy of climate policy } \\
\text { - Rejection of mitigation } \\
\text { pathways, demand of } \\
\text { termination of current mitigation } \\
\text { efforts, changes in guiding } \\
\text { principles toward growth and } \\
\text { development }\end{array}$ & $\begin{array}{l}\text { - Aim at demonstrating balanced } \\
\text { assessments but critique of } \\
\text { current measures as problems } \\
\text { - Discuss different options, } \\
\text { but eventually favor specific } \\
\text { complementary mitigation and } \\
\text { adaptation options } \\
\text { - Reject specific options }\end{array}$ \\
\hline $\begin{array}{l}\text { Rhetorical } \\
\text { devices }\end{array}$ & $\begin{array}{l}\text { - Dramatizing rhetorical devices: } \\
\text { visualizing metaphors and vivid } \\
\text { wording }\end{array}$ & $\begin{array}{l}\text { - Dramatizing rhetorical devices: } \\
\text { visualizing metaphors and vivid } \\
\text { wording }\end{array}$ & $\begin{array}{l}\text { - Pejorative wording and } \\
\text { visualizing metaphors } \\
\text { - Neutral and impersonal wording }\end{array}$ \\
\hline
\end{tabular}


such as 'trend and variability', 'science and gut feeling', 'guilt and cause', 'rationality and irrationality', 'serenity and anxiety'. The ideal course is not an easy one, but it is feasible if we do not transgress the solid ground of reason [...] even if it is difficult sometimes" (C27).

\section{Discussion and Conclusions}

Our article asked how researchers position themselves in the Austrian newspaper coverage of climate change. We identified three types of researchers that vary considerably in their understanding of climate change, the representation of climate science, and the content of policy-recommendations: alerters, critics, and objectivists. Finally, we discuss our findings against the background of existing scholarly works on the nationally specific media representation of climate research regarding (a) the frequency of occurrence of the three types, (b) the specific features of the types, and (c) the observed tendency toward the politicization of climate science.

First, our study found that alerters were by far the most frequently represented in Austrian newspapers, followed by objectivists and critics. This dominance of the alerter type strongly corresponds with media analyses of other countries. Scholars identify similar types, "advocates" or "alarmists", as the most frequently appearing type in newspaper coverage of climate change in Germany, the US, and the UK (Grundmann 2OI4). The prevalence of this type is not surprising and may reflect the scientific state of the art (i.e., the consensus on anthropogenic climate change) (Cook et al. 20I6). Although advocates/alarmists/alerters in the scholarly literature have been identified as the most prominent position, studies indicate significant differences in the frequency of occurrence and the relevance of skeptical voices among countries. Similar to Austria, Germany (e.g., Neverla/Schäfer 2OI2; Schäfer/Schlichting 2OI4) and Sweden (e.g., Berglez et al. 2009) exhibit a low representation of skeptics in media discourse (Boykoff/Boykoff 2007; Post 2009). In contrast, the US media give the alarming and skeptical types almost equal voices, even if this balance does not representatively illustrate the strong scientific consensus on anthropogenic climate change (Boykoff/ Boykoff 2004; 2007; Neverla/Schäfer 2012; Rhomberg 2OI2). Scholars explain the tendency to disproportionally represent "skeptics" in the US with the firm adherence to journalistic norms of objectivity, balance, and pluralism (Boykoff/Boykoff 2004; 2007; Neverla/Schäfer 2OI2; Rhomberg 20I2). At the same time, the overrepresentation of skeptics might partly result from the more adversarial political culture of the US, which is characterized by more contentious ways of decision-making and fact-finding and involves an extremely broad spectrum of actors covering all relevant positions and interests on an issue to a similar extent (Jasanoff 2005). By comparison, the strong political culture of neo-corporatism in Austria is conducive to the representation of consensual positions (Brand/Pawlow 20I4; Pregernig 2005). Rather than emphasizing opposing views, political and societal debates exhibit a considerable orientation toward political, societal, and scientific consensus and compromise. In this regard, the Austrian knowledge culture (Pregernig 2005) might account for the apparently neutral, balanced objectivists. From this perspective, objectivists might reflect a politico-cultural inclination toward consensus, compromise, and mediation.

Second, beyond the strong focus on identifying types of researchers in the existing literature, we reconstructed their specific strategies and lines of argumentation to convey their perspectives. To reflect these different discursive strategies, we named the identified types accordingly. Our analysis revealed that the three types draw on varying thematic foci to present their understanding of climate change and corresponding policy recommendations. Alerters warn of the natural and social impacts of anthropogenic climate change and directly address climate policy, whereas critics indirectly provide their perspective on policy approaches by primarily criticizing the role of science. Objectivists deliberately distinguish themselves from both of these types and aim to convey a neutral and objective position. Our in-depth characterization allows for a comparison with existing typologies and an enrichment of their descriptions. Alerters share some significant features with the "alarmists" (Risbey 2008) and "convinced warners" (Post 2009) identified in the US and Germany. These types stress the anthropogenic component of climate change and call for immediate, mandatory, and comprehensive political actions (Boykoff/Boykoff 2004; Post 2009; Risbey 2008). In addition to demanding actions to combat climate change, alerters in Austrian newspapers strongly emphasize warning about inaction. Critics combine features of Rahmstorf and Schellnhuber's (2007) "attribution skeptics", "impact skeptics", and "action skeptics". However, no "trend skeptics", who basically deny the existence of climate change, were found in Austrian newspapers. Similar to "global warming skeptics" (Boykoff/Boykoff 2004), "skeptics" (Grundmann/Scott 20I4), and "skeptical observers" (Post 2009) in the US and Germany, most critics stress that natural rather than anthropogenic factors account for the phenomenon. However, some critics in Austrian newspapers question the extent of anthropogenic contributions to climate change but not their existence. The different skeptical researchers identified in other media analyses directly advocate cautious and voluntary measures or a "wait-and-see approach" (Boykoff/Boykoff 2007). In our case, critics more strongly focus on criticizing cur- 
rent approaches, principles, and measures and calling for a change of the structures of science-policy interactions rather than suggesting specific political measures. Although some scholars identify researchers positioned between the alarming and skeptical types (e.g., Post 2009), it is difficult to find a type that matches our objectivists. Objectivists in Austrian newspapers locate themselves between alarmists and critics but ultimately adopt a clear political position.

Third, our analysis points to a strong politicization of climate science in Austrian media coverage. All three types of researchers invoke scientific authority to position themselves politically and provide specific recommendations for action or inaction. Alerters and objectivists primarily introduce scientific expertise to warn of inaction and to stress the urgency of actions. Additionally, they emphasize which specific political measures and options they prefer. In contrast, critics reject national and international climate policy. The strategy of critics and objectivists of distinguishing themselves from specific scientific institutions or certain researchers and their way of representing knowledge contributes to the politicization of science. The politicization of climate science in the media has also been observed in other countries (Berglez et al. 2009; for Sweden, see Neverla/Schäfer 2012; for Germany, see Schäfer et al. 20I2) and might at least partly be explained by journalistic norms and practices as well as researchers adapting to these. On the one hand, journalists purposefully select researchers known to represent a specific stance on climate policy. Journalists frequently demand a clear positioning on climate change effects, ask for concrete recommendations, and aim to transfer statements to a national, regional or emotional level to make complex and abstract issues more easily understood for their audiences (Neverla/Trümper 20I2). On the other hand, researchers adapt to the anticipated media standards by showing alarmism, simplifying findings, and using specific semantics (Schäfer et al. 2012). They frequently provide clear utterances on policy solutions in media contexts even if they would hesitate to position themselves that clearly in an academic context (Rhomberg 2012). Although politicization is frequently observed, it is not pervasive. In a study on Swedish newspaper reporting on forest-related climate issues, the authors revealed the contrasting phenomena of abstraction, depoliticization, and scientification. Researchers confined themselves to the problem description and explanation, did not attribute responsibility to actors, and refused to provide clear-cut solutions (Kleinschmit/Sjöstedt 20I4).

Our discussion illustrated that the positioning of researchers in Austrian newspaper coverage reveals some similarities to other countries, but significant variances between countries also exist. Although the similarities can mainly be attributed to the global scientific consen- sus and journalistic norms and procedures, the differences seem related to different political cultures. Future research could more systematically compare media representations of climate science across countries to identify factors related to scientific consensus, journalistic norms, media culture, and political culture.

\section{References}

Anderson, Alison (2009), Media, Politics and Climate Change: Towards a New Research Agenda, in: Sociology Compass, Vol. 3(2), I66-182, Internet: http://dx.doi. org/IO.IIII/j.I75I-9020.2008.00I88.x.

Antilla, Liisa (2005), Climate of Scepticism: US Newspaper Coverage of the Science of Climate Change, in: Global Environmental Change, Vol. 15(4), 338352, Internet: http://dx.doi.org/IO.IoI6/j.gloenvcha.2005.08.003.

Berglez, Peter/Birgitta Hoijer/Ulrika Olausson (2009), Individualization and Nationalization of the Climate Issue. Two Ideological Horizons in Swedish News Media, in: Boyce, Tammy/Justin Lewis (eds.), Climate Change and the Media, New York: Peter Lang Publishing, 2II-225.

Beyrl, Maria/Flooh Perlot (2006), Politische Kommunikation in Österreich - Generalverdacht der Inszenierung?, in: Österreichsiche Zeitschrift für Politikwissenschaft, Vol. 35(4), 39I-405.

Boykoff, Maxwell T. (2007), From Convergence to Contention: United States Mass Media Representations of Anthropogenic Climate Change Science, in: Transactions of the Institute of British Geographers, Vol. 32(4), 477-489, Internet: http://dx.doi.org/IO.IIII/j.I4755661.2007.00270.x.

Boykoff, Maxwell T. (2013), Public Enemy No. I? Understanding Media Representations of Outlier Views on Climate Change, in: American Behavioral Scientist, Vol. 57(6), 796-817, Internet: http://dx.doi. org/IO.II77/0002764213476846.

Boykoff, Maxwell T./Jules M. Boykoff (2004), Balance as Bias: Global Warming and the US Prestige Press, in: Global Environmental Change, Vol. I4(2), I25136, Internet: http://dx.doi.org/Io.IoI6/j.gloenvcha.2003.I0.00I.

Boykoff, Maxwell T./Jules M. Boykoff (2007), Climate Change and Journalistic Norms: A Case-Study of US Mass-Media Coverage, in: Geoforum, Vol. 38, II90I204, Internet: http://dx.doi.org/Io.IOI6/j.geoforum. 2007.01.008.

Brand, Ulrich/Adam Pawlow (2014), Selectives at Work: Climate Concerns in the Midst of Corporatist Interests. The Case of Austria., in: Journal of Environmental Protection, Vol. 5, 780-795, Internet: http://dx.doi. org/IO.4236/jep.2OI4.59080. 
Bundeskanzleramt (20I4), Medien in Österreich. Vienna: Bundeskanzleramt.

Carvalho, Anabela (2007), Ideological Cultures and Media Discourses on Scientific Knowledge: Re-reading News on Climate Change, in: Public Understanding of Science, Vol. I6(2), 223-243, Internet: http://dx.doi. org/IO.II77/0963662506066775.

Cook, John/Naomi Oreskes/Peter T. Doran/William R. L. Anderegg/Bart Verheggen/Ed W. Maibach/J. Stuart Carlton/Stephan Lewandowsky/Andrew G. Skuce/Sarah A. Green/Dana Nuccitelli/Peter Jacobs/Mark Richardson/ Bärbel Winkler/Rob Painting/Ken Rice (2016), Consensus on Consensus: A Synthesis of Consensus Estimates on Human-Caused Global Warming, in: Environmental Research Letters, Vol. II, Internet: http:// dx.doi.org/IO.IO88/1748-9326/11/4/048002/pdf.

Digital Affairs. (2016), "Social Media Radar Austria.”, Internet: http://socialmediaradar.at (Access: 08.IO.2016).

Dunlop, Claire A. (2013), Epistemic Communities, in: Araral, Eduardo/Michael Howlett/Scott Fritzen/M. Ramesh/Xun $W u$ (eds.), Routledge Handbook of Public Policy, London, 229-243.

Filzmaier, Peter/Peter Plaikner/Karl A. Duffek (eds.) (2007), Mediendemokratie Österreich, Vienna: Facultas Verlag.

Gläser, Jochen/Grit Laudel (2010), Exerteninterviews und qualitative Inhaltsanalyse als Instrumente rekonstruierender Untersuchungen, Wiesbaden: VS Verlag für Sozialwissenschaften.

Grundmann, Reiner/Mike Scott (2014), Disputed Climate Science in the Media: Do Countries Matter?, in: Public Understanding of Science, Vol. 23(2), 220-235, Internet: http://dx.doi.org/Io.II77/0963662512467732.

Haas, Peter M. (1992), Introduction: Epistemic Communities and International Policy Coordination, in: International Organization, Vol. 46(I, Winter 1992), I-35.

Hallin, Daniel C./Paolo Mancini (2004), Comparing Media Systems. Three Models of Media and Politics, Cambridge: Cambridge University Press.

Hustedt, Thurid (2013), Analyzing Policy Advice: The Case of Climate Policy in Germany, in: Central European Journal of Public Policy, Vol. 7(I), 88-IIO.

Jasanoff, Sheila (1990), The Fifth Branch: Science Advisers as Policymakers, Cambridge, MA: Harvard University Press.

Jasanoff, Sheila (2005), Designs on Nature. Science and Democracy in Europe and the United States, Princeton: Princeton University Press.

Kaltenbrunner, Andy/Matthias Karmasin/Daniela Kraus/ Astrid Zimmermann (2007), Der Journalisten-Report, Vienna: Facultas Verlag.

Kleinschmit, Daniela /Viveca Sjöstedt (2014), Between Science and Politics: Swedish Newspaper Reporting on Forests in a Changing Climate, in: Environmental Sci- ence \& Policy, Vol. 35, II7-I27, Internet: http://dx.doi. org/IO.IOI6/j.envsci.2013.02.0II.

Knorr Cetina, Karin (1991), Epistemic Cultures: Forms of Reason in Science, in: History of Political Economy, Vol. 23(I), IO5-I22, Internet: http://dx.doi. org/IO.I215/OOI82702-23-I-IO5.

Lengauer, Günther/Fritz Plasser/Gilg Seeber (2012), Media Milieus: Politische Informations- und Mediennutzungstypen, in: Plasser, Fritz (ed.), Erfolgreich Wahlkämpfen. Massenmedien und Wahlkampagnen in Österreich, Vienna: Facultas Verlag, 57-85.

Magin, Melanie/Birgit Stark (201I), Österreich - Land ohne Leuchttürme? Qualitätszeitungen im Spannungsfeld zwischen publizistischer Leistung und strukturellen Zwängen, in: Blum, Roger/Heinz Bonfadelli/Kurt Imhof/Otfried Jarren (eds.), Krise der Leuchttürme öffentlicher Kommunikation, Wiesbaden: VS Verlag für Sozialwissenschaften, 97-II4.

Moser, Susanne C. (2010), Communicating Climate Change: History, Challenges, Process and Future directions, in: Wiley Interdisciplinary Reviews: Climate Change, Vol. I(I), 3I-53, Internet: http://dx.doi.org/ IO.IOO2/wcc.II.

Neverla, Irene /Mike S. Schäfer (2012), Einleitung: Der Klimawandel und das „Medien-Klima“, in: Neverla, Irene/Mike S. Schäfer (eds.), Das Medien-Klima, Wiesbaden: VS Verlag für Sozialwissenschaften, 9-25.

Neverla, Irene/Stefanie Trümper (2OI2), Journalisten und das Thema Klimawandel: Typik und Probleme der journalistischen Konstruktionen von Klimawandel, in: Neverla, Irene/Mike S. Schäfer (eds.), Das MedienKlima. Fragen und Befunde der kommunikationswissenschaftlichen Klimaforschung, Wiesbaden: VS Verlag für Sozialwissenschaften, 95-II8.

Oreskes, Naomi (2004), Science and Public Policy: What's Proof Got To Do With It?, in: Environmental Science \& Policy, Vol. 7(5), 369-383, Internet: http://dx.doi. org/IO.IOI6/j.envsci.2004.06.002.

Oreskes, Naomi/Erik M. Conway (2010), Merchants of Doubt. How a Handful of Scientists Obscured the Truth on Issues from Tabacco Smoke to Global Warming, New York: Bloomsbury Press.

Pelinka, Anton (2003), Das politische System Österreichs, in: Wolfgang Ismayr (ed.), Die politischen Systeme Westeuropas, Opladen: Leske + Budrich, 52 I-552.

Peters, Hans Peter (20I3), Gap between Science and Media Revisited: Scientists as Public Communicators, in: Proceedings of the National Academy of Sciences, Internet: http://dx.doi.org/IO.IO73/pnas.I2I2745IIO.

Pielke, Roger A. (2007), The Honest Broker: Making Sense of Science in Policy and Politics, Cambridge: Cambridge University Press.

Plasser, Fritz (ed.) (2010), Politik in der Medienarena: Praxis politischer Kommunikation in Österreich, Vienna: Facultas Verlag. 
Plasser, Fritz/Peter A. Ulram (2003), Striking a Responsive Chord: Mass Media and Right-Wing Populism in Austria, in: Mazzoleni, Gianpietro/Julianne Stewart/ Bruce Horsfield (eds.), The Media and Neo-Populism: A Contemporary Analysis, Westport: Praeger Publishers, $2 \mathrm{I}-43$.

Post, Senja (2009), Klimakatastrophe oder Katastrophenklima? Die Berichterstattung über den Klimawandel aus Sicht der Klimaforscher, BadenBaden: Nomos Verlagsgesellschaft.

Pregernig, Michael (2005), Wissenschaftliche Politikberatung als kulturgebundene Grenzarbeit: Vergleich der Interaktionsmuster in den USA und Österreich, in: Bogner, Alexander/Helge Torgersen (eds.), Wozu Experten? Ambivalenz der Beziehung von Wissenschaft und Politik, Wiesbaden: VS Verlag für Sozialwissenschaften, 267-290.

Rahmstorf, Stefan/Hans Joachim Schellnhuber (2007), Der Klimawandel, München.

Rhomberg, Markus (2012). Wissenschaftliche und politische Akteure in der Klimadebatte, in: Neverla, Irene/ Mike S. Schäfer (eds.), Das Medien-Klima. Fragen und Befunde der kommunikationswissenschaftlichen Klimaforschung, Wiesbaden: VS Verlag für Sozialwissenschaften, 29-45.

Risbey, James S. (2008), The New Climate Discourse: Alarmist or Alarming?, in: Global Environmental Change, Vol. I8(I), 26-37, Internet: http://dx.doi.org/ IO.IOI6/j.gloenvcha.2007.06.003.

Sarewitz, Daniel (2004), How Science Makes Environmental Controversies Worse, in: Environmental Science \& Policy, Vol. 7(5), 385-403, Internet: http://dx.doi. org/IO.IoI6/j.envsci.2004.06.00I.

Schäfer, Mike S./Ana Ivanova/Inga Schlichting/Andreas Schmidt (2012), Mediatisierung: Medienerfahrungen und -orientierungen deutscher Klimawissenschaftler, in: Neverla, Irene/Mike S. Schäfer (eds.), Das Medien-Klima. Fragen und Befunde der kommunikationswissenschaftlichen Klimaforschung, Wiesbaden: VS Verlag für Sozialwissenschaften, 233-252.

Schäfer, Mike S./Inga Schlichting (2014), Media Representations of Climate Change: A Meta-Analysis of the Research Field, in: Environmental Communication, Vol. 8(2), I42-I6o, Internet: http://dx.doi.org/IO.IO80/I75 24032.20I4.9I4050.

Seethaler, Josef/Gabriele Melischek (2006), Die Pressekonzentration in Österreich im europäischen Vergleich, in: Österreichische Zeitschrift für Politikwissenschaft, Vol. 35, 337-36o.

Spruijt, Pita/Anne B. Knol/Eleftheria Vasileiadou/Jeroen Devilee/Erik Lebret/Arthur C. Petersen (2014), Roles of Scientists as Policy Advisers on Complex Issues: A Literature Review, in: Environmental Science \& Policy, Vol. 4O(I), I6-25, Internet: http://dx.doi.org/IO.IOI6/ j.envsci.2014.03.002.
Statistik Austria (20I3), Reichweite der österreichischen Tageszeitungen 2010 bis 2OI2, Vienna: Statistik Austria.

Whitmarsh, Lorraine (20II), Scepticism and Uncertainty about Climate Change: Dimensions, Determinants and Change OverTime, in: Global EnvironmentalChange, Vol.2I(2),690-700,Internet:http://dx.doi.org/IO.IOI6/ j.gloenvcha.20II.oI.oI6.

Wirth, Veronika/Andrea Prutsch/Torsten Grothmann (2014), Communicating Climate Change Adaptation. State of the Art and Lessons Learned from ten OECD Countries, in: GAIA, Vol. 23(I), 30-39, Internet: http:// www.scopus.com/inward/record.url? eid=2-s2.o84898477 I 4 I \& partnerID $=40 \&$ md $5=7$ a6c 7 d8fce 3 b5 d 8dba5aae6b4b8953b6.

\section{Authors}

Andrea Tony Hermann (year of birth 1986) is a political scientist and PhD student at the Institute of Forest, Environmental, and Natural Resource Policy (InFER) of the University of Natural Resources and Life Sciences, Vienna (BOKU). She works as researcher at the Institute for Strategy Analyses (ISA). Her research interests are science-policy interactions in climate policy, policy advice in different politico-cultural contexts, the representation of science in the media, political cultures, regional development, and rural areas.

Markus Pikl (year of birth 1987) holds a Master's Degree in Environment and Bio-Ressources Management of the University of Natural Resources and Life Sciences of Vienna. His research interests are the intersection of political theory and environmental science.

Anja Bauer (year of birth 1977) is a political scientist, working at the Institute of Technology Assessment (ITA) at the Austrian Academy of Sciences. She researches and teaches in the areas of environmental, sustainability and technology governance with a special interest in the role of expertise, anticipation and participation in policy-making. 
